\title{
Spatial and temporal variation of drought impact on black locust (Robinia pseudoacacia L.) water status and growth
}

\author{
Dario Mantovani ${ }^{(1-2)}$, Maik \\ Veste $^{(1-3)}$, Christian Böhm ${ }^{(1)}$, \\ Marco Vignudelli ${ }^{(4)}$, Dirk Freese ${ }^{(1)}$
}

\begin{abstract}
Stimulated by the rising demand for bioenergy, forestry practices for energy production are of increasing importance worldwide. Black locust (Robinia pseudoacacia L.) is a suitable tree species for biomass production in shortrotation plantations in East Germany, especially on marginal land where insufficient water and nutrients are a limiting factor for tree growth. Our study aims to clarify the spatial and temporal variability of the black locust growth through the analysis of the plant water status, and to evaluate the effect of adverse edaphic conditions on growth performances, amplified by periods of summer drought. The study was carried out at two sites presenting comparable climatic but different edaphic conditions: (i) fertile agricultural soil; and (ii) heterogeneous unstructured soil from a reclaimed post-mining area. During the vegetation period, the growth rate decreased in both sites following the plant water status in terms of pre-dawn leaf water potential. Particularly in the post-mining area, due to the adverse edaphic conditions, below the critical pre-dawn water potential value of $-0.5 \mathrm{MPa}$, the stem growth was drastically reduced during a period of summer drought. However, the trees could cope with the extreme soil and weather conditions in the post-mining site without perishing.
\end{abstract}

Keywords: Agroforestry, Drought Stress, Soil Water Availability, Soil Heterogeneity, Reclamation red, and therefore plant growth depends mostly on the amount of rainfall. In those areas characterized by unfavorable edaphic conditions (Hüttl \& Weber 2001), the soil is mostly an unstructured clayed-sandy material, extremely heterogeneous and poor in organic materials and nutrients. As a result (Bungart et al. 2000), a decrease in productivity is to be expected, due to the scarcity of nutrients. Furthermore, the soil water availability during summer is more prone to water deficit than in agricultural soils under the same climatic conditions. Since water and nutrient availability are the main limiting factors for primary production, there is a need to evaluate the drought impact on the black locust growth $\square$ (1) Brandenburg University of Technology Cottbus-Senftenberg, Institute of Soil Protection and Recultivation, Konrad-Wachsmann-Allee 6, D-03046 Cottbus (Germany); (2) CRA-OLI Centro di Ricerca per l'Olivicoltura, v. Nursina 2, I-06049 Spoleto (PG - Italy); (3) CEBra Centre for Energy Technology Brandenburg e.V., Friedlieb-Runge-Strasse 3, D-03046 Cottbus (Germany); (4) University of Bologna, Department of Agricultural Sciences, v. Fanin 44, I40127, Bologna (Italy)

@ Dario Mantovani (mantdar2@gmail.com)

Received: Mar 26, 2014 - Accepted: May 15, 2015

Citation: Mantovani D, Veste M, Böhm C, Vignudelli M, Freese D (2015). Spatial and temporal variation of drought impact on black locust (Robinia pseudoacacia L.) water status and growth. iForest 8: 743-747. - doi: 10.3832/ifor1299-008 [online 2015-06-18]

Communicated by: Gianfranco Minotta performance, taking into account the response of the plant to different edaphic conditions. There are several research works carried out at field scale, describing the black locust biomass production and its relation to water constraint (Bongarten et al. 1992). The link between the black locust growth and the soil water availability has been recently clarified by Mantovani et al. (2014a, 2014b), however only in a controlled lysimeter experiment. Therefore, in our work we aimed at evaluating the impact of summer drought periods and nutrient paucity on black locust growth performance in the field, linking the plant water status to the radial increment of the trunk during the vegetation period. The spatial and temporal variability in leaf water potential and its implications for tree growth was taken into account. More specifically we carried out a critical comparison between black locust growth performance under water limitation in two sites with different edaphic but comparable climatic conditions.

\section{Material and method}

\section{Study sites}

The study area is located in southern Brandenburg, Germany, about $150 \mathrm{~km}$ southeast of Berlin and is characterized by an average annual precipitation of $556 \mathrm{~mm}$ and a mean annual temperature of $9.3^{\circ} \mathrm{C}$ (1951-2003, nearest climatic station Cottbus, Deutscher Wetterdienst). 
Fig. 1 - Schematic diagram of the tree plantation in Forst and Welzow-Süd. The figures are not in scale and the circles in the figure are only representative of the tree rows, not of the single trees.

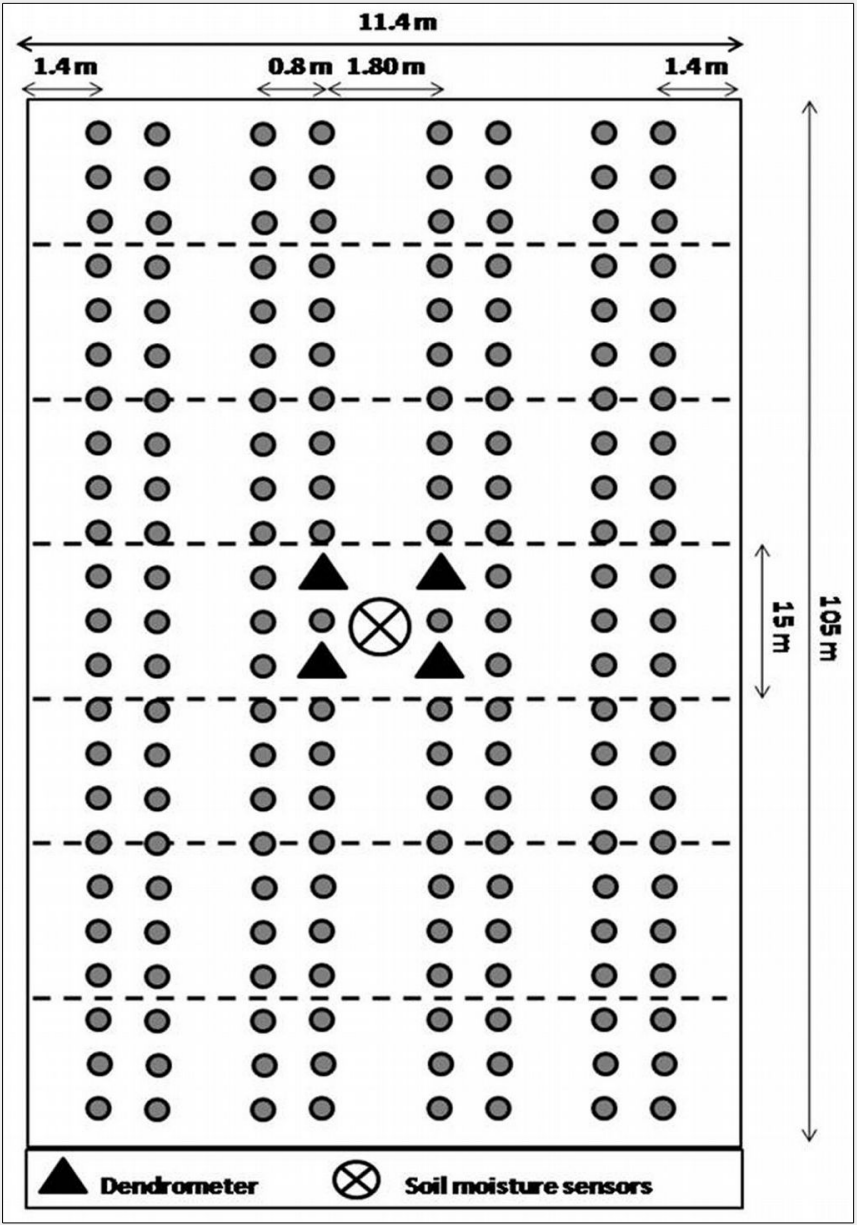

For the experiment two different sites were chosen: (i) Forst ( $51^{\circ} 47^{\prime} 24^{\prime \prime} \mathrm{N}, 14^{\circ} 37^{\prime}$ $\left.57^{\prime \prime} \mathrm{E}\right)$, a fertile agricultural field characterized by sandy loam soil (Gleysol - FAO 2006). While located close to the river Neiße, the annual variation of the ground water table lies between 1.0 and $2.2 \mathrm{~m}$ below the soil surface. (ii) Welzow-Süd $\left(51^{\circ}\right.$ $\left.37^{\prime} 23^{\prime \prime} \mathrm{N}, 14^{\circ} 19^{\prime} 34^{\prime \prime} \mathrm{E}\right)$, a reclaimed postmining site with a groundwater table lower than $100 \mathrm{~m}$ below the soil surface due to the ongoing mining activity. The soil here is heterogeneous and consists mainly of sands and clayed-sands in an initial stage (Regosol - FAO 2006), therefore it is still unstructured (Krümmelbein et al. 2012). The total organic carbon (TOC) measured in Forst $\left(10.1 \mathrm{~g} \mathrm{~kg}^{-1}\right)$ was higher than in Welzow-Süd ( $2.9 \mathrm{~g} \mathrm{~kg}^{-1}$ ), while the total nitrogen (TN) values amounted to $0.9 \mathrm{~g} \mathrm{~kg}^{-1}$ in both sites.

Black locust bare-root seedlings were planted in Forst in the spring of 2010 and in Welzow-Süd in the spring of 2007. The plants were established in form of an agroforestry system as a short-rotation coppice for bioenergy production. The design of the agroforestry system at both sites was comparable. The tree hedgerows consisted of four double rows. Along the row the trees were planted every $0.85 \mathrm{~m}$. The tree distance within and between the double rows was $0.8 \mathrm{~m}$ and $1.8 \mathrm{~m}$, respectively. Crop alleys in between the hedgerows had a width of $24 \mathrm{~m}$. One plot of $11.4 \times 105 \mathrm{~m}$ was selected at each site (Fig. 1), and split in 7 subplots of $11.4 \times 15 \mathrm{~m}$.

Air temperature, relative humidity and precipitation values were measured using weather stations and stored on data loggers (Delta-T devices Ltd., Cambridge, UK) in 10 min intervals.

\section{Hydrological soil characteristics}

The saturated hydraulic conductivity $(K s)$ was determined in undisturbed soil cores $(100 \mathrm{~cm})$ sampled at both sites at 5, 20, and $40 \mathrm{~cm}$ depths in six replicates. We chose the permanent head method using a lab permeameter (Eijkelkamp, Giesbeek, Netherlands). After measuring the $K s$, the bulk density of the same cores was determined by oven-drying at $105{ }^{\circ} \mathrm{C}$ until constant weight of cores was reached.

\section{Plant growth and plant water status}

For each subplot four fully developed trees were selected. The monthly tree growth was recorded by measuring the diameter at breast height $(\mathrm{DBH})$ with a polyethylene caliper. At the beginning of the experiment, in the spring of 2012 the mean DBH was $18.4 \pm 4 \mathrm{~mm}$ in Forst and $35.4 \pm 8 \mathrm{~mm}$ in Welzow-Süd, which suggest that, despite the adverse edaphic conditions, tree growth can be considered relatively normal also in the latter site. In addition, the daily growth rate of the four selected trees was evaluated with dendrometers (DDL, Ecomatik, Dachau, Germany) at breast height at both sites. The selected trees were located in the center of the tree rows (in the subplots $\mathrm{W}_{4}$ and $\mathrm{F}_{4}$ - see Fig. 1). The plant water status of 56 selected trees was evaluated periodically, measuring the pre-dawn leaf water potential $\left(\Psi_{\mathrm{pd}}\right)$ of three leaves per tree, using the Scholander pressure chamber (Plant Water Status Console 3000, Soilmoisture Inc., Santa Barbara, CA, USA). The pre-dawn leaf water potential was measured starting two hours before sunrise. The trees were georeferenced by using a differential GPS system (Trimble R8 GNSS /R6 /5800, Dayton, Ohio, USA). The spatial information, together with the $\Psi_{\text {pd }}$ values, was integrated into a Geographic Information System (ARCGIS Spatial Analyst software, ESRI, Redland, CA, USA) and used to create a dynamic map.

\section{Statistical analysis}

A non-parametric analysis Mann-Whitney U-Test $(\alpha<0.05)$ was performed to compare the two sites in terms of: (i) bulk density; (ii) saturated hydraulic conductivity; (iii) mean cumulative daily diameter increment, measured in the subplots $\mathrm{F}_{4}$ and $\mathrm{W}_{4}$; (iv) mean $\Psi_{\mathrm{pd}}$ recorded during the same day in different subplots within the same site. The non-parametric Spearmans' $\rho$ correlation $(\alpha<0.01)$ was applied to link the mean weekly growth rates to the $\Psi_{\mathrm{pd}}$. The analyses were carried out using the IBM SPSS $^{\oplus}$ version 21 (SPSS Inc. Chicago, IL, USA). For the geospatial analysis the ARCGIS Spatial Analyst software (ESRI) was used. Spatial and temporal variations of the $\Psi_{\mathrm{pd}}$ were evaluated by interpolating the $\Psi_{\text {pd }}$ values obtained in the different subplots during the vegetation period with the inverse distance weighted interpolation method (IDW).

\section{Results}

\section{Climatic conditions}

The mean daily air temperature and the vapor pressure deficit (VPD) at both study sites are shown in Fig. 2. In Welzow-Süd $30 \%$ and in Forst $25 \%$ of the measured days had a mean daily temperature lying between 20 and $25^{\circ} \mathrm{C}$. The VPD instead showed more variation between the two sites, with $33 \%$ and $16 \%$ of the days above $5 \mathrm{hPa}$ $\mathrm{Pa}^{-1}$ for Welzow-Süd and Forst, respectively (Fig. 2b). The global radiation at both sites was comparable, with values higher than $200 \mathrm{Wm}^{-2}$ for approximately $60 \%$ of the days (Fig. 3a). During the vegetation period the total rainfall in Welzow-Süd amounted to $238 \mathrm{~mm}$, while in Forst $301 \mathrm{~mm}$ were recorded (Fig. 3b), the daily amount for each sites is shown in Fig. 4.

\section{Hydraulic conditions and soil moisture}

The mean bulk density of the Gleysol in Forst was $1.6 \mathrm{~g} \mathrm{~cm}^{-3}$ and the $K s$ values measured at 5,20 , and $40 \mathrm{~cm}$ depth were 59 , 


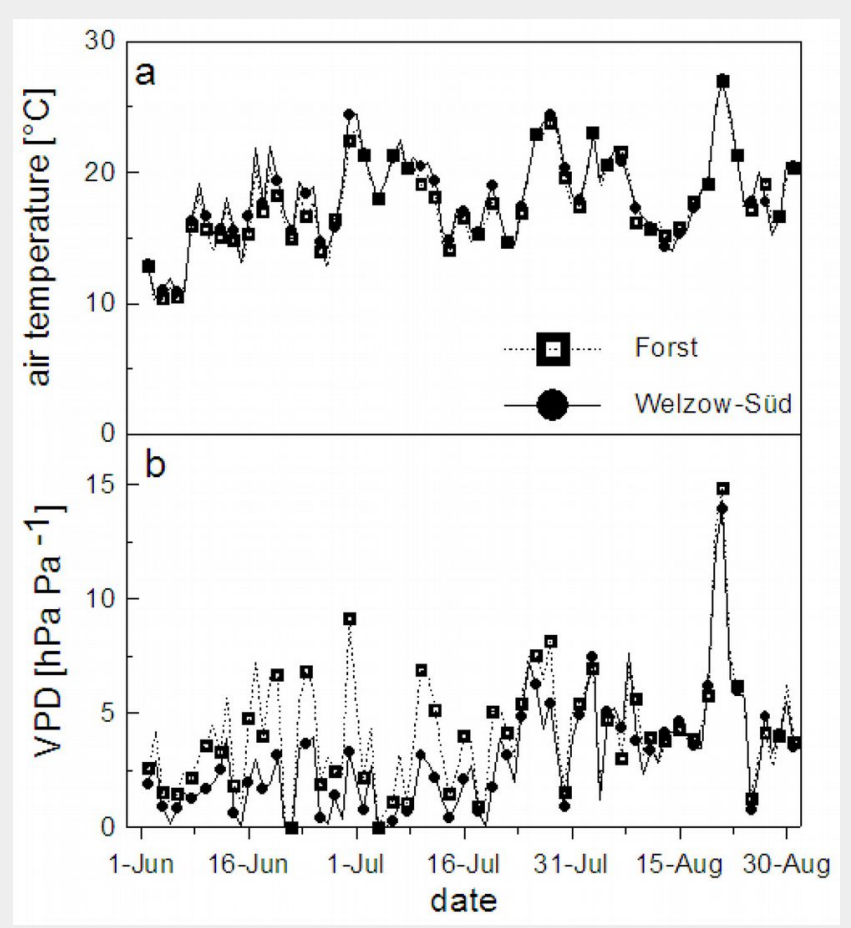

Fig. 2 - Daily mean air temperature (a) and daily mean vapor pressure deficit (b) measured at Forst and Welzow-Süd during the vegetation period (from June $1^{\text {st }}$ to August $30^{\text {th }}, 2012$ ).

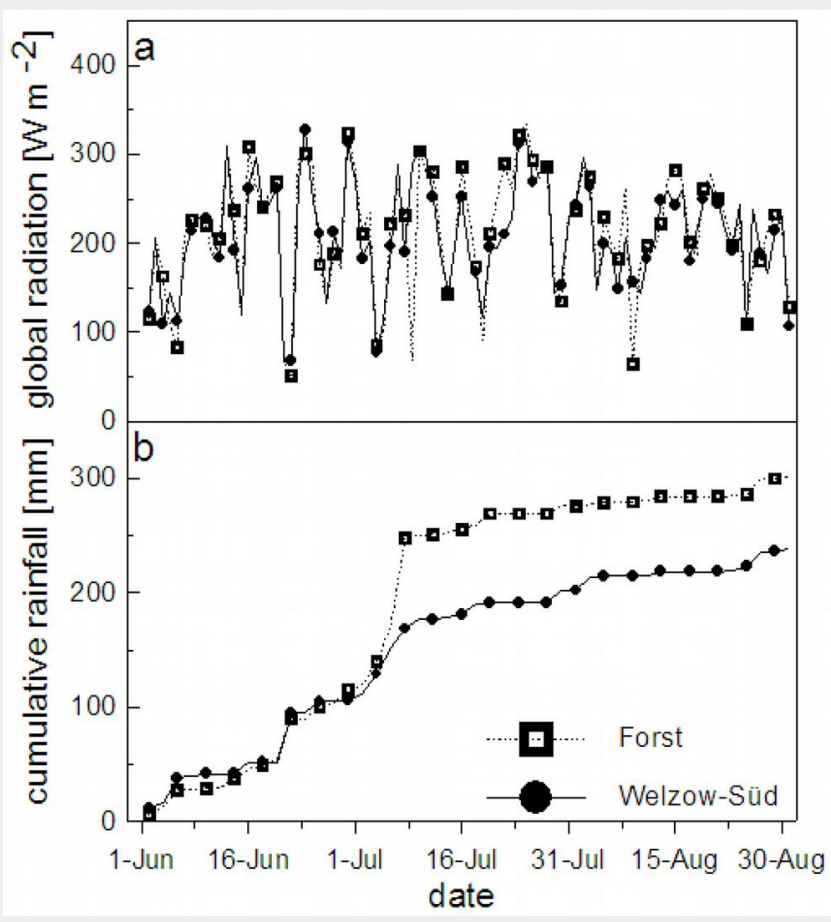

Fig. 3 - Daily mean global radiation (a) and cumulative rainfall (b) measured at Forst and Welzow-Süd during the vegetation period (from June $1^{\text {st }}$ to August $30^{\text {th }}, 2012$ ).
17 , and $27 \mathrm{~cm}$ day $^{-1}$ respectively. Although the structureless Regosol sampled in Welzow-Süd presented a comparable bulk density $\left(1.7 \mathrm{~g} \mathrm{~cm}^{-3}\right)$, the $K s$ was significantly higher, varying between values of $559(\mathrm{p}=$ $0.032), 223(p=0.036)$ and $73(p=0.42) \mathrm{cm}$ day $^{-1}$, measured at 5,20 , and $40 \mathrm{~cm}$ depth respectively.

\section{Daily diameter increment}

The dendrometers installed in the subplots $\mathrm{F}_{4}$ and $\mathrm{W}_{4}$ recorded the daily diameter growth and we found no significant difference $(p=0.067)$ between the sites until July 25, 2012 (Fig. 5). The difference only became significant $(p=0.038)$ towards the end of the experiment when in Welzow-

Süd the plant diameter increased only $52 \%$ of the plants established in Forst.

Weekly growth and plant water status The plant water status $\left(\Psi_{\mathrm{pd}}\right)$ in the subplots $\mathrm{F}_{4}$ and $\mathrm{W}_{4}$ became more negative in the final stages of the experiment (Fig. 6). In August both sites faced a summer drought period, which affected the tree growth. The correlation between the weekly diameter increment rate and the $\Psi_{\mathrm{pd}}$ was significant $(\mathrm{p}=0.689)$ only in Welzow-Süd, and their relation was better described by a logarithmic function ( $Y=$ $\left.-0.13 \cdot \log (X)+0.09, r^{2}=0.60\right)$ with a drastic decrease of the diametric increment following the $\Psi_{\mathrm{pd}}$ reduction (Fig. 7b).

\section{Spatial variation of pre-dawn water potential}

Until July 25, 2015 for all the subplots measured at both sites the mean $\Psi_{\mathrm{pd}}$ values were >-0.5 MPa. At the Forst site, the mean $\Psi_{\mathrm{pd}}$ values decreased for all subplots until the mean minimum of $-0.81 \mathrm{MPa}$ was reached on August 24, and no significant differences between the subplots were found. Conversely, starting from August 14 the mean $\Psi_{\mathrm{pd}}$ decreased drastically at the Welzow-Süd site, reaching the minimum mean values of $-1.56 \mathrm{MPa}$ on August 24 . Here, the differences between the subplots in terms of $\Psi_{\mathrm{pd}}$ became significant (p $=0.028$ ), ranging from $-2.06 \mathrm{MPa}$ in subplot W4 to $-0.96 \mathrm{MPa}$ in subplot W6. The soil

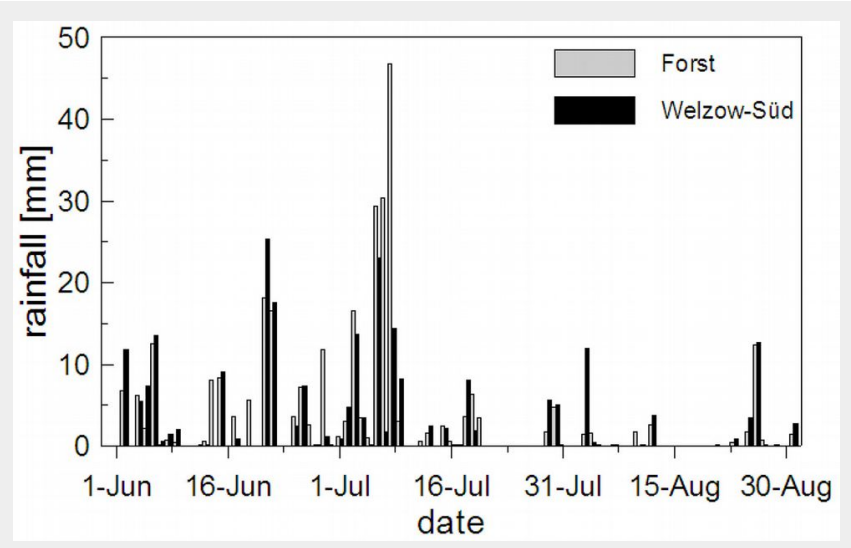

Fig. 4 - Daily rainfall amount at Forst (a) and Welzow-Süd (b) recorded during the vegetation period (from June $1^{\text {st }}$ to August $30^{\text {th }}$ 2012).

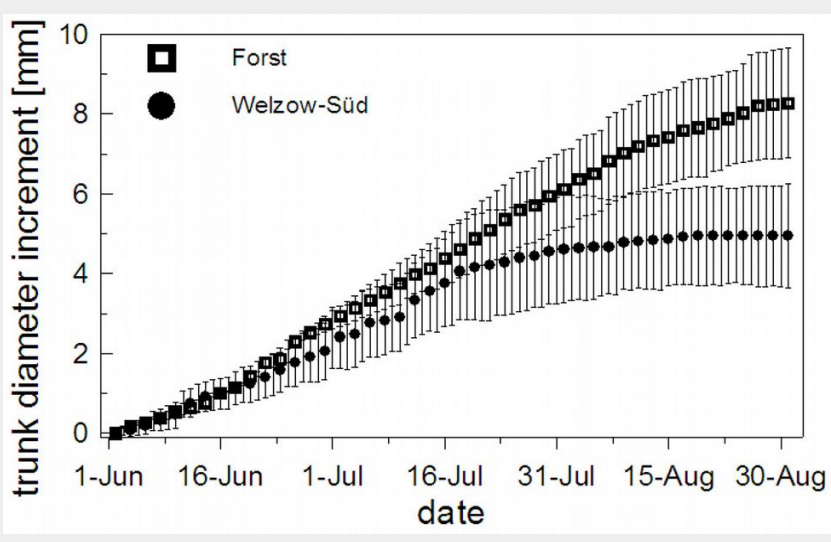

Fig. 5 - Mean and standard deviation of the trunk diameter increment measured in the F4 subplot (Forst) (a) and W4 subplot (Welzow-Süd) (b) during the vegetation period (from June $1^{\text {st }}$ to August $30^{\text {th }}, 2012$ ). 


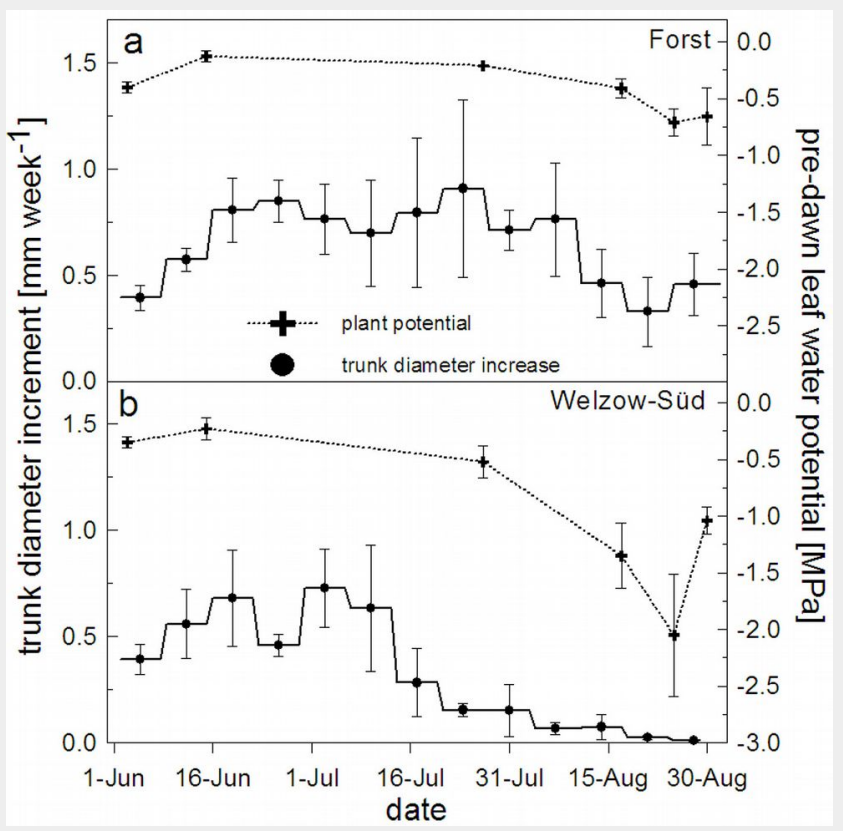

Fig. 6 - Pre-dawn leaf water potential and weekly diameter increase of trees in Forst (a) and Welzow-Süd (b) measured during the vegetation period (from June $1^{\text {st }}$ to August $30^{\text {th }}$, 2012).

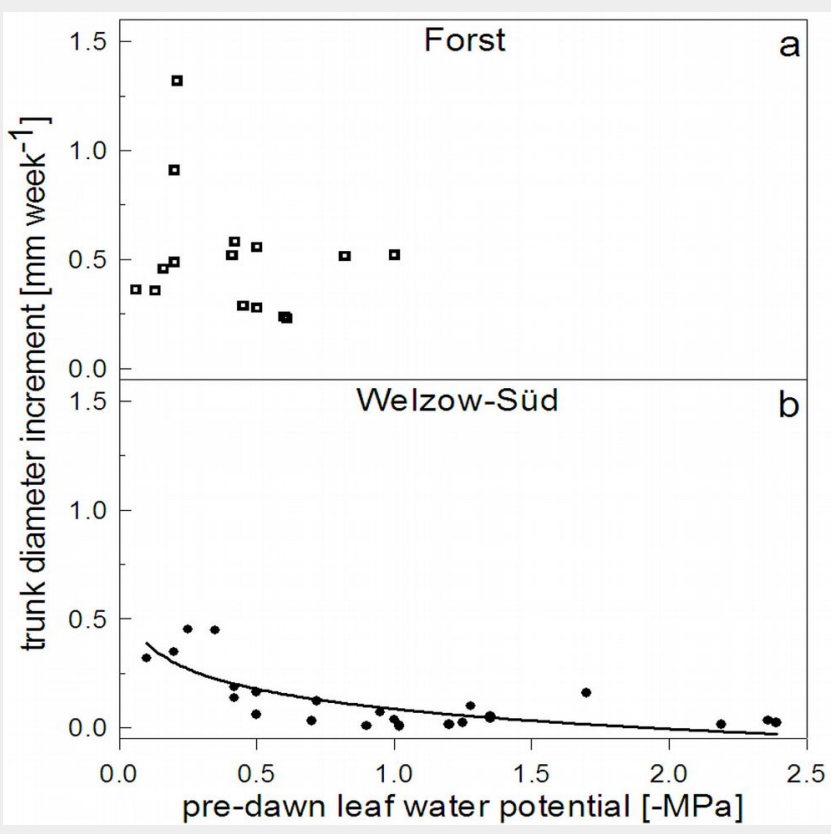

Fig. 7 - Weekly trunk diameter increase in relation to the predawn leaf water potential of trees at the F4 subplot (Forst) (a) and W4 subplot (Welzow-Süd) (b) measured during the vegetation period (from June $1^{\text {st }}$ to August $30^{\text {th }}, 2012$ ).

heterogeneity recorded at Welzow-Süd is well described by the spatial and temporal variation of the $\Psi_{\mathrm{pd}}$ evaluated at this site (Fig. 8).

\section{Discussion}

Besides the difference in precipitation, which led to an increased water input in Forst, the different soil characteristics such as soil texture and TOC influenced the satu-

rated hydraulic conductivity and the water holding capacity of the soil at both sites, enhancing its water storage capacity. The growth rate variation recorded at the two sites became relevant from July onwards, when the $\Psi_{\mathrm{pd}}$ reduction occurred in Welzow-Süd. Here the growth decrement was probably caused by the combined effects of the reduced precipitation and soil water storage, higher VPD values and low nu-

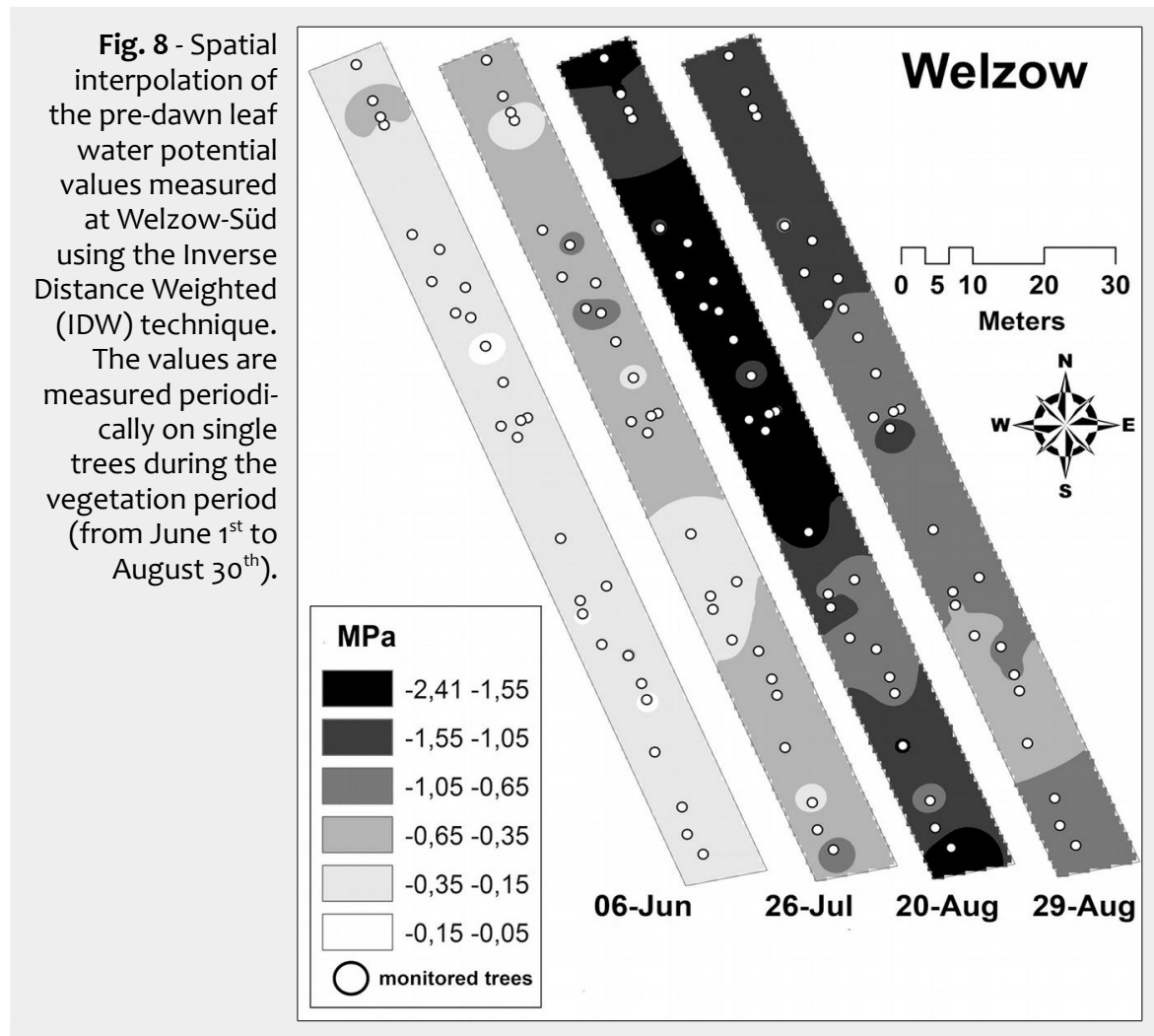

trient availability. Consequently, stomatal closure and the reduction of the leaf area under drought conditions limited the transpiration (Bréda et al. 2006, Mantovani et al. 2014a, 2014b), and enabled the trees to tolerate long-term drought conditions due to its ecophysiological and morphological adaptations (Xu et al. 2009, Veste \& Kriebitzsch 2013). However, the reduction of the $\mathrm{CO}_{2}$ uptake had drastic effects on the plant growth and consequently on the biomass production, as reported by Mantovani et al. (2014a, 2014b), where the primary production was directly proportional to the water used, independently from the drought stress frequency and duration. Instead, water constraint caused changes in the soil-root and leaf-atmosphere interfaces. Consequently, $\mathrm{CO}_{2}$ uptake and transpiration decrease limited the tree growth, and in extreme cases the tree survival was at stake. The heterogeneity recorded in Welzow-Süd in terms of plant growth was related to the $\Psi_{\mathrm{pd}}$ and mirrored the heterogeneous soil property which caused the water availability variation in space and time, described by the dynamic maps in Fig. 8. During the night the water potential of a non-transpiring plant equilibrated with the wettest water potential of the soil around the root system (Ritchie \& Hinckley 1975). As recorded by Veste et al. (2008), the spatial heterogeneity of soil water availability is linked with the pre-dawn water potential of trees under water limitation. In addition to water constraint, the indirect effect of the nutrient uptake reduction did occur, caused by the poor edaphic conditions at Welzow-Süd. However, since the diametric increment was higher in Forst than in Welzow-Süd at similar water poten- 
tial values, other factors such as different tree ages and better soil conditions and nutrition may have contributed to increase the primary production in Forst. Robinia pseudoacacia is less dependent on the uptake of nutrients in comparison to other broad leaf trees because of its capability to fix biological nitrogen even under extreme edaphic conditions, as they are found in post-mining sites (Veste et al. 2013) or under drought conditions (Mantovani et al. 2013, Wurzburger \& Miniat 2014). Nevertheless, Kanzler et al. (2015) has observed for Robinia an increase of the growth rates after phosphate fertilization in WelzowSüd. The fact that limited phosphate, in combination with low Molybdenum availability in the soil, has an impact on the biological nitrogen fixation was confirmed by Wurzburger et al. (2012). Those differences in soil nutrients might partly explain the differences in the absolute growth rate between sites, while temporal and spatial differences within sites depend on the tree access to soil water.

\section{Conclusions}

The black locust growth performance is severely affected by the temporal and spatial variation of the leaf water potential, which varies according to the soil typology and water availability. Further nutrient deficiency may inhibit root expansion, causing the reduction of water uptake which indirectly influences the leaf water potential as well. If the water and nutrient uptake is limited due to critical edaphic conditions, which were site-specific in our experiment, the tree growth stops during a longer drought period. However, due to its morphological and ecophysiological adaptations R. pseudoacacia is able to cope with the extreme soil conditions in post-mining sites. Therefore, black locust could be an alternative species to be grown in postmining areas, where the competition with food crops is reduced and soil protection and rehabilitation is the main goal. The spatial and temporal variation of the growth performance in such post-industrial areas can be simply quantified by using the predawn leaf water potential method, evaluating at the same time the degree of soil heterogeneity in the area.

\section{References}

Bongarten BC, Huber, DA, Apsley, DK (1992). Environmental and genetic influences on shortrotation biomass production of black locust (Robinia pseudoacacia L.) in the Georgia Piedmont. Forest Ecology and Management 55(1): 315-331. - doi: 10.1016/0378-1127(92)90108-L

Bréda N, Huc R, Granier A, Dreyer E (2006). Temperate forest trees and stands under severe drought: a review of ecophysiological responses, adaptation processes, and long-term consequences. Annals of Forest Science 63 (6): 625-644. - doi: 10.1051/forest:2006042

Bungart R, Bens O, Hüttl RF (2000). Production of bioenergy in post-mining landscapes in Lusatia: perspectives and challenges for alternative land use systems. Ecological Engineering 16: 516. - doi: 10.1016/S0925-8574(00)00046-X

Böhm C, Quinkenstein A, Freese D, Hüttl RF (2011). Assessing the short rotation woody biomass production on marginal post-mining areas. Journal of Forest Science 57 (7): 303-311. [online] URL: http://www.cabdirect.org/abstra cts/20113296917.html

FAO (2006). IUSS Working Group WRB 2006. World reference base for soil resources. World Soil Resources Reports No. 103, Food and Agriculture Organization of the United Nations, Rome, Italy.

Grünewald H, Böhm C, Quinkenstein A, Grundmann P, Eberts J, Von Wühlisch G (2009). Robinia pseudoacacia L.: a lesser known tree species for biomass production. BioEnergy Research 2 (3): 123-133. - doi: 10.1007/s12155-0099038-x

Hüttl RF, Weber E (2001). Forest ecosystem development in post-mining landscapes: a case study of the Lusatian lignite district. Naturwissenschaften 88 (8): 322-329. - doi: 10.1007/s001 140100241

Kanzler M, Böhm C, Freese D (2015). Impact of P fertilization on the growth performance of black locust (Robinia pseudoacacia L.) in a lignite post-mining area in Germany. Annals of Forest Research 58 (1). - doi: 10.15287/afr.2015.303 Krümmelbein J, Bens $O$, Raab $T$, Naeth AM (2012). A history of lignite coal mining and reclamation practices in Lusatia, eastern Germany. Canadian Journal of Soil Science 92 (1): 53-66. - doi: 10.4141/cjss2010-063

Mantovani D, Veste M, Boldt-Burisch K, Fritsch S, Freese D (2013). Black locust (Robinia pseudoacacia L.) root growth response to different irrigation regimes. Verhandlungen der Gesellschaft für Ökologie 43: 333. [online] URL: http://www.opus4.kobv.de/opus4-UBICO/front door/index/index/docld/9394
Mantovani D, Veste M, Freese D (2014a). Effects of drought frequency on growth performance and transpiration of young black locust (Robinia pseudoacacia L.). International Journal of Forestry Research 2014, Article ID 821891, pp. 11. - doi: $10.1155 / 2014 / 821891$

Mantovani D, Veste M, Freese D (2014b). Black locust (Robinia pseudoacacia L.) ecophysiological and morphological adaptations to drought and their consequence on biomass production and water use efficiency. New Zealand Journal of Forestry 44: 29. [online] URL: http://www. biomedcentral.com/content/pdf/s40490-0140029-0.pdf

Ritchie GA, Hinckley TM (1975). The pressure chamber as an instrument for ecological research. Advances in Ecological Research 9: 165254. - doi: 10.1016/S0065-2504(08)60290-1

Veste M, Kriebitzsch WU (2013). Einfluss von Trockenstress auf Photosynthese, Transpiration und Wachstum junger Robinien (Robinia pseudoacacia L.) [Influence of drought stress on photosynthesis, transpiration, and growth of juvenile black locust]. Forstarchiv 84: 35-42. [in German with English summary] [online] URL: http://www.desertconsult.de/paper2013/ FA-Robinie_2013.pdf

Veste $M$, Staudinger M, Küppers M (2008). Spatial and temporal variability of soil water in drylands: plant water potential as a diagnostic tool. Forestry Studies in China 10 (2): 74-80. doi: 10.1007/s11632-008-0022-x

Veste M, Böhm C, Quinkenstein A, Freese D (2013). Biologische Stickstoff - Fixierung der Robinie [Biological nitrogen fixation of Robinina]. AFZ-Der Wald 2/2013: 40-42.

Weih M (2004). Intensive short rotation forestry in boreal climates: present and future perspectives. Canadian Journal of Forest Research 34 (7): 1369-1378. - doi: 10.1139/x04-090

Wurzburger N, Miniat CF (2014). Drought enhances symbiotic di-nitrogen fixation and competitive ability of a temperate forest tree. Oecologia 174: 1117-1126. - doi: 10.1007/s00442-013-28510

Wurzburger $\mathrm{N}$, Bellenger JP, Kraepiel AML, Hedin LO (2012). Molybdenum and phosphorus interact to constrain asymbiotic nitrogen fixation in tropical forests. PLoS One 7 (3): e33710. doi: 10.1371/journal.pone.0033710

Xu F, Guo W, Wang R, Xu W, Du N, Wang Y (2009). Leaf movement and photosynthetic plasticity of black locust (Robinia pseudoacacia L.) alleviate stress under different light and water conditions. Acta Physiologiae Plantarum 31 (3): 553-563. - doi: 10.1007/s11738-008-0265-0 